\title{
Projeto de extensão Desafio: compromisso social, formação docente e ensino
}

\author{
superior
}

\section{Project Desafio (Challenge): social consciousness, teatcher education and higher education}

\author{
Helenara Plaszewski Facin, Denise Dalpiaz Antunes \\ Universidade Federal de Pelotas, Rio Grande do Sul, Brasil
}

\begin{abstract}
Resumen
O texto apresenta um projeto extensionista da UFPel/Brasil: Desafio Pré-Universitário Popular, gratuito, em que os acadêmicos licenciandos, atuam como voluntários, propiciando uma formação para a docência. Entre ensinar e aprender, vislumbra-se no exercício da práxis a ação-reflexão-ação e na conscientização de que a educação não é neutra, mas ato político. A principal reflexão acerca dessa prática educativa do/no Desafio, estão nos pressupostos Freireanos, de que não é possível realizar a leitura da palavra, sem relacioná-la com a leitura de mundo, pois a educação não é um ato mecânico de decodificar escritas sem conexão, mas de conscientização do significado das palavras.

Palavras-chave: projeto de extensão, desafio: préuniversitário, educação popular, formação de professores, ensino superior
\end{abstract}

\begin{abstract}
This text presents a project implemented by UFPel/Brazil: Desafio Pré-Universitário Popular. In this project, teacher education students act as volunteers, which is part and parcel of their education. Between teaching and learning, we can see a práxis exercise of action-reflectionaction, and at the conscious level that education isn't neutral, but a political act. At the core of this educational practice of/at Desafio is Freire's assumption that it isn't possible to understand the reading word without connecting it to the World, because this isn't a mechanical act of decodifying writing, but to be aware of the meaning of the words.

Key Words: extension Project, desafio: pré-universitário, popular education, teatcher's formation, higher education
\end{abstract}

\section{Introdução}

É preciso considerar que a universidade, como lócus de produção, de consolidação e de socialização do conhecimento, que tem como compromisso o desenvolvimento de projetos integrados, que estabeleçam ações calcadas no tripé ensino, pesquisa e extensão, devem assumir uma atitude de integração entre as instâncias, promovendo espaço e desenvolvimento à comunidade a qual faz parte, para que a indissociabilidade não seja contemplada apenas enquanto afirmação de um princípio institucional.
No entanto, ao referir-nos aos idos dos anos 90, a realidade da universidade pública não era assim, ainda caracterizado como ente partidariamente vinculado aos interesses do setor privado e demarcado historicamente por reforçar as injustiças sociais e a intensificação dos processos de exclusão social. Com isto, a universidade como outras instâncias configura-se por uma enorme dívida social no sentido do alargamento dos direitos sociais coletivos, ou seja, da esfera pública.

Neste período, mais precisamente em agosto de 1993 surge o empreendimento e labor na execução do projeto Desafio Pré-Vetibular que não foi nascido em preceitos da academia, mas sim, em um sentimento mais grandioso e ao mesmo tempo tão mais simples, baseado na crença de homem, apostar na educação desde, ainda que seja simplesmente, dentro de um curso pré-vestibular.

A proposta do Desafio parte de um princípio básico de solidariedade e no dever moral que um grupo de estudantes da Universidade Federal de Pelotas (UFPel) detinham em relação a uma sociedade que sustenta o ensino superior, sem ter a contraprestação devida por parte da universidade. Neste sentido, Freire afirma que "[...] na medida em que nos tornamos capazes de transformar o mundo, de dar nome às coisas, de perceber, de inteligir, de decidir, de escolher, de valorar de, finalmente, eticizar o mundo, o nosso mover-nos nele e na história vem envolvendo necessariamente sonhos por cuja realização nos batemos. (FREIRE, 2014, p.35).

Na obra Pedagogia da Indignação Freire aponta que os sonhos são indispensáveis para a transformação da realidade. Na verdade, a transformação do mundo a que o sonho aspira é um ato político e seria uma ingenuidade não reconhecer que os sonhos têm seus contra-sonhos. E que o momento de que uma geração faz parte, porque histórico, revela marcas antigas que envolvem compreensões da realidade, interesses de grupos, de classes, preconceitos, gestação de ideologias que se vêm perpetuando em contradição com aspectos mais modernos (FREIRE, 2014).

Nisso, "o conhecimento não se estende do que se julga sabedor até aqueles que se julga não saberem; o conhecimento se constitui nas relações homem-mundo, relações de transformação, e se aperfeiçoa na 
problematização crítica destas relações" (FREIRE, 1996, p. 36).

Assim, explica-se o surgimento deste curso prévestibular gratuito que luta pela exclusão cansativa e repetitiva em nossa terra, que afasta milhões de jovens trabalhadores que sonham em um dia estar na universidade. Como o próprio nome sugere o Desafio de proporcionar a classe trabalhadora 0 acesso à Universidade Pública e Gratuita.

A proposta teve como objetivo principal romper com as barreiras do academicismo e colocar em prática um espaço de construção com segmentos locais. A meta principal era possibilitar o acesso de segmentos locais menos favorecidos economicamente a uma cultura elaborada e como consequência disso a aprovação no vestibular, para que sendo participes tenham maiores condições de uma intervenção social mais consciente. No seu trabalho, sempre de grupo e como decisões coletivas, busca-se instaurar a sal de aula como espaço de cultura, debate e construção de uma nova visão das relações sociais.

Tal posição condiz com a assertiva de Paulo Freire quando afirma que "[...] nosso papel não é de falar ao povo sobre nossa visão de mundo ou tentar impô-la a ele, mas dialogar com ele sobre a sua e a nossa. [...] A ação educativa e política não pode prescindir do conhecimento crítico, dessa situação, sob pena de se fazer "bancaria" ou de se pregar no deserto. [...] precisamos estar convencidos de que o convencimento dos oprimidos de que devem lutar por sua libertação não é doação que lhes faça a liderança, mas resultado de sua conscientização" (FREIRE, 1978, p.29).

Nesse contexto, o projeto pedagógico busca trazer a tona a realidade vivencial do aluno, discutindo as questões reais vividas, nos bairros, vilas, na administração pública, nas fábricas, enfim buscar discutir a problemática social onde está inserido nosso(a) aluno(a). Estas pessoas que conosco interagem são trabalhadores, filhos de trabalhadores ou jovens excluídos da educação básica.

Neste sentido, este texto tem como escopo apresentar a origem, a proposta de um projeto que sobrevive a mais de 24 anos, e que em alguns momentos esteve sem um professor responsável. E neste ano ele está cadastrado com o nome Desafio Pré-Universitário Popular na plataforma da instituição como um projeto unificado, por entender a importância que ele tem, possibilitando um espaço de formação, troca de experiências, saberes e comprometimento com a comunidade local, mas, que ainda se faz necessário dar maior visibilidade para que a comunidade acadêmica participe ativamente das diversas ações que ele propõe e possibilitar maior acesso a comunidade externa, por oportunizar as classes excluídas o acesso a universidade pública.

\section{Princípios e a metodologia do Projeto}

O Projeto é composto predominantemente por estudantes de graduação e pós-graduacão e ex-alunos do Desafio. Também há uma equipe executiva que se ocupa das atividades de coordenação de disciplina, coordenação pedagógica, coordenação geral do curso, secretaria e biblioteca e demais colaboradores.

Estamos vinvulados institucionalmente com a Próreitoria de Cultura e Extensão da universidade, órgão ao qual proporciona os recursos financeiros (locação do prédio, vigilância, portaria, material diversos, etc).

Como princípios e fio condutor buscamos um viés pela Educação Popular, mas cada equipe de educadores tem autonomia para decidir a metodologia utilizada na condução de suas atividades.

Conseguimos propiciar aos estudantes da graduação e pós-graduação da Universidade Federal de Pelotas um maior desenvolvimento pessoal e profissional de suas habilidades, envolvendo-os de maneira direta os acadêmicos em uma atividade com o segmento estudantil secundarista local.

Além disso, buscamos oportunizar linhas de ação voltadas que visam todos os atores desse processo: aulas ministradas toda semana por áreas do conhecimento, oficinas, espaços de formação sobre Educação Popular, aulões nos finais de semana abertos a comunidade para debater diversos assuntos do cotidiano, tomando como pontos os princípios de crítica e ação - criticar aquilo que é opressor e restritivo as pessoas, possibilitando pensar a liberdade e o bem-estar. Trabalhar com a racionalidade emancipatória, através das relações dialéticas entre o contexto histórico-social-político-cultural como um todo.

Portanto, acreditamos num processo de ensinoaprendizagem na perspectiva Freireana que: somos seres inacabados, estamos sempre em processo de aprender; ensinar não é transmitir conhecimentos, nem tão pouco aprender é acumular conhecimento; o mais importante é aprender a pensar, pensar a realidade e não reproduzi-la; só aprendemos o que é significativo para a vida, e o sujeito aprende em contato com o outro.

Neste contexto, as experiências proporcionam um processo de ensino-aprendizagem vivo, um espaço de vida, rico de sentidos, de descobertas, voltado para a realidade da aplicabilidade das ideias e conhecimentos. Assim compreender, o sentido de como educadores não somos detentores do saber, segundo FREIRE (1996, p. 47): "saber que ensinar não é transferir conhecimento, mas, criar as possibilidades para a sua própria produção ou a sua construção", assumindo-se como sujeitos do processo, pois a ação, a interação e a troca, movem o processo de aprendizagem.

A reflexão que devemos ter claro na perspectiva freireana é que não é possível realizar a leitura da palavra, sem relacioná-la com a leitura de mundo, pois não se trata a educação como um ato mecânico de decodificar escritas sem conexão, mas conscientizá-los do significado das palavras. Pensar no amanhã, através da busca pela superação de limites e afirmação dos sonhos e da esperança.

Além disso, partimos do entendimento da perspectiva positiva, de esperança e de utopias, que se identifica com as concepções de ensino de Freire (1999), no livro a Pedagogia da Esperança. A esperança faz parte da natureza humana, num movimento de constante busca, de que professor e aluno, juntos, podem aprender e ensinar.

Acreditamos que o professor deve considerar conceitos importantes em relação ao ensino-aprendizagem e sua 
relação, para poder planejar uma ação mais consistente com a realidade e a necessidade dos alunos. Da mesma forma, estabelecer uma boa relação professor-aluno, constitui parte integrante do processo educativo. Essa relação está presente no ato de ensinar, quando o professor adota uma postura de respeito, como defende Freire (1996, p.47):

Quando entro em uma sala de aula devo estar aberto a indagações, à curiosidade, às perguntas dos alunos, a suas inibições; um ser crítico e inquiridor, inquieto em face da tarefa que tenho - a de ensinar e não transferir conhecimento.

O professor, tomando essa postura, consegue buscar uma aproximação com o aluno, identificando as ricas possibilidades e possíveis dificuldades de aprendizagem.

Assim movidos por estes ideais comprometidos com a afirmação do ser humano, com a indignação frente a toda e qualquer atitude que se constitua enquanto transgressão aos valores e direitos humanos.

\section{Contexto histórico}

O Desafio não é simplesmente um projeto extensionista da UFPel, mas, é o exercício da transdisciplinaridade e da indissociabilidade do ensino-pesquisa-extensão, em que os alunos da graduação ou da pós-graduação se formarão e darão dentro desta oportunidade, horas de suas vidas, para ajudar um outro jovem ou adulto sequioso de saber.

$\mathrm{Na}$ característica deste projeto fica evidente a aproximação da comunidade em situação de vulnerabilidade social, que está excluída socialmente do acesso aos bancos universitários. Então, buscamos alcançar o maior número de pessoas dos bairros periféricos da cidade de Pelotas, através da utilização pedagógica do levantar dúvidas incentivadoras da busca pelo conhecimento. Desta forma, buscando transcrever e a refazer métodos, mecanismos para a investigação crítica, numa pedagogia que promova o combate a todos os tipos de preconceitos, percebendo, assim, algo que já está esquecido em nossa geração - a Pedagogia da Esperança.

Para Freire (1996), educação é o compromisso do educador em fazer dela um instrumento de mudança na sociedade em vivemos. Mas, vale destacar que as problemáticas sociais existentes no passado como: o analfabetismo, a desigualdade social, a massificação e outras mazelas, resistem as transformações e não foram superadas em nossa contemporaneidade.

Então, apontamos como referencial teórico o mais importante educador brasileiro Paulo Reglus Neves Freire, que fez de sua obra um legado que "inaugurou" a pedagogia crítica, influenciando muitos professores, ao propor uma Educação Libertadora, voltada a postura dialógica em sala de aula, bem como o desenvolvimento de uma consciência crítica, como forma de participar ativamente da sociedade em que está inserido que é essencial ao processo de libertação.

Nestes moldes, o aluno passa a ser o protagonista do processo e o professor não é mais o detentor do saber, aquele que sabe e transmite os conteúdos de ensino. Nesta postura pedagógica que é criticada e denominada por Freire (1978) de educação bancária significa: "um ato de depositar, em que os educandos são os depositários e o educador o depositante" (FREIRE, 1978, p.66) - e os conteúdos, o depósito.

Portanto, não acreditamos nesse modelo, porque a prática do professor é uma atividade mecânica, desvinculada da prática social, uma mera transferência de conteúdo, que não leva em conta que o conhecimento é produzido pelo aluno. O professor é um mero emissor do conhecimento e o aluno o receptor, aquele que tudo recebe pronto e deve reproduzir aquilo que lhe foi transmitido.

$\mathrm{Na}$ perspectiva da educação tradicional, o aluno chega com a 'cabeça vazia', cabendo ao professor colocar-lhe um conjunto de conhecimentos já constituídos; pode-se identificar a atuação do aluno a partir de verbos como receber, guardar, memorizar e arquivar, o que não produz significados e conhecimento.

Diferente disto, perseguimos uma concepção de educação numa perspectiva crítica, reflexiva e investigativa, uma das condições fundamentais para a concretização do princípio do direito a uma educação de qualidade.

Via educação devemos colocar poder nas mãos dos alunos, promovendo a democracia, o respeito as diferenças e o diálogo em sala de aula, isto tudo, impulsiona o pensar crítico, um olhar à nossa existência e ao mundo, através da reflexão desveladora das injustiças, das mentiras ideológicas que ocorre nas relações da sociedade com a escola, e assim, objetiva agir na sociedade em busca de melhorias.

Sabe-se também, que o ato educativo se realiza em espaços que não se restringem à escola, estando presente, com efeito, em diversas instâncias e processos, dentro e fora de instituições. Realiza-se por pessoas que, interessando-se pelas questões que a perpassam, seja como possibilidade de ampliação de seus saberes, seja pela reflexão das próprias práticas, seja para conhecer mais acerca desse campo.

Nesse sentido, este projeto via extensão tem como "locus" privilegiado do conhecimento a interlocução com a sociedade, construindo novos e diferentes saberes, e muitas vezes, a extensão acaba suprindo lacunas do Estado na execução de suas políticas públicas, que por vez estão descoladas da realidade local.

\section{Considerações reflexivas}

O texto possibilitou-nos apresentar o projeto de extensão Desafio: Pré-Universitário Popular vinculado a Pró-Reitoria de Extensão da na Universidade Federal de Pelotas vislumbrando um compromisso de se constituir num espaço de Educação Popular e de formação inicial para a docência dos educadores que atuam no projeto.

Como viés teórico perseguimos uma prática em sala de aula ancoradas no pensamento freireano do respeito ao ser humano, comprometidos com a educação popular, a qual permite aos desvalidos da sorte, o sonho e a utopia como fomentadores da esperança. Nessa ação educativa, levaremos o aluno a compreensão não ingênua da realidade, mas a leitura de mundo, em contraposição as determinantes sociais, porque numa sociedade em que 
convivem segmentos da população com interesses opostos, não existe educação neutra.

Assim podemos inferir que incentivamos a coletividade, a horizontalidade e a conscientização e como proposto Freire (1980, p.20): “deve preparar, ao mesmo tempo para um juízo crítico das alternativas propostas pela elite, e dar a possibilidade de escolher o próprio caminho". Também não se pode furtar ao debate acerca das condições de possibilidades de criação e recriação da vida, dos sentidos da educação e da discussão acerca de nosso papel como cidadão.

Por tudo, foram estas algumas discussões trazidas para este texto, e ao mesmo tempo, para que não se perca no projeto o horizonte da Educação Popular e que esse olhar seja expresso e evidenciado em todos os momentos. Por acreditarmos que o projeto extencionista propicia o espaço de ensinar e aprender, o exercício da praxis açãoreflexão-ação, a conscientixação de que a educacão não é neutra, mas tem um caráter politico, bem como salientar o papel da universidade e de seus estudantes para o desenvolvimento técnico, científico e pedagógico enquanto instituição de ensino para a cidade de Pelotas e Região - ao buscar construir uma sociedade mais justa, solidária e menos excludente.

\section{Referências}

Freire, Paulo. (2014). Pedagogia da Indignação: cartas pedagógicas e outros escritos. Organização e participação Ana Maria Araújo Freire. São Paulo: Paz e Terra.

Freire, Paulo. (1999). Pedagogia da Esperança: um reencontro com a pedagogia do oprimido. 6. Ed. São Paulo: Paz e Terra.

Freire, Paulo. (1996). Pedagogia da Autonomia: saberes necessários à prática educativa. São Paulo: Paz e Terra.

Freire, Paulo. (1980). Conscientização: teoria e prática da libertação: uma introdução ao pensamento de Paulo Freire. 3. Ed. São Paulo: Moraes.

Freire, Paulo. (1978). Pedagogia do Oprimido. Rio de Janeiro: Paz e Terra. 